\title{
Muslims through Storytelling: Islamic Law, Culture and Reasoning in South Sulawesi
}

Komunitas: International Journal of Indonesian Society and Culture 10(1) (2018): 131-146

DOl:10.15294/komunitas.v9i1.16269 (C) 2018 Semarang State University, Indonesia p-ISSN 2086 - 5465 | e-ISSN 2460-7320 http://journal.unnes.ac.id/nju/index.php/komunitas

UNNDS JOURNALS

\author{
Moh Yasir Alimi \\ Affiliaion Sociology and Anthropology, Social Science Faculty, Universitas Negeri Semarang, Indonesia
}

Received: 10 April 2017; Accepted: 1 March 2018; Published: 30 March 2018

\begin{abstract}
This article explores the use of storytelling by the Muslims of South Sulawesi in their efforts to confront the formalization of Islamic law in the province. My specific objective is to nuance the existing approach to Islam and Muslim life, which to date focuses on scriptural argumentation, or analytical reasoning based on the Quran and other Islamic sources. The exclusive focus on scriptural argumentation as the main approach to explain Islam does not help us to understand how Muslims use non-analytical forms of human communication in response to shari'a formalization. The experiences of Muslims in South Sulawesi demonstrates that storytelling can be a meaningful and direct means to express Islamic identity and to challenge the formalization of shari'a. In the hierarchies of reasoning used in South Sulawesi by Muslims, scriptural argumentation is not the most important.
\end{abstract}

\section{Keywords}

Muslims; storytelling; shari'a; discourses; South Sulawesi

\section{INTRODUCTION}

When I introduced myself at the beginning of my fieldwork in South Sulawesi, Indonesia, Puang Ridho, an elderly man, told me: "A long time ago a prince of our kingdom left for Java; and now our prince has returned!" Hearing his comment, I was flattered, and laughter welled inside me: "How could a person leave as a prince and return as an ordinary person like me?" I thanked Puang Rido for his warm welcome, but I did not take his comment seriously. Only after hearing many stories and exploring their functions did I understand the meaning and importance of storytelling in the village's social imagination. For the residents of South Sulawesi, storytelling is more than spice for conversation. It is a device to engage and situate newcomers to the village, within the local social imaginary. Through storytelling, the residents explain the place they inhabit, write their community's life history, express opinions and feelings, and, above all, respond to new social circumstances and changes in their lives.

Storytelling penetrates deeply within the fabric of religious life. The Muslims of South Sulawesi, who have a reputation as one of the most devout Muslim communities in the world, use storytelling to produce a local form of Islam that is theatrical, expressive, and rich in rituals (Alimi 2014b). When these indigenous expressions of Islam are challenged by the Islamist project of

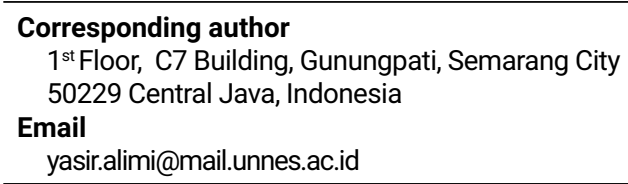


shariahisation, i.e., the attempts to formalize shari'a in local politics, Muslims use storytelling to defend their local Islamic tradition. The use of storytelling to confront the formalization of shari'a is illustrated by the tales of Kahar Muzakkar, the leader of Darul Islam, an armed rebellion in South Sulawesi that lasted from 1955 to 1965 , which sought to establish an Islamic state in Eastern Indonesia with Islamic Law as its state constitution. The Darul Islam struggle ended in 1965 when Kahar was shot to death, but his dreams of Islamic law were revived by Islamists after the collapse of the Soeharto regime in 1998. Subsequently, stories about him circulated in which he is still alive and a divine saint. Those stories directly confront the formalization of sharia by inverting the image of Kahar Muzakkar and celebrating local forms of Islamic traditions. In fact, Kahar was a modernist, textual minded, proponent of the sharia state, anti-Sufi form of Islam, and a critic of local Islamic traditions. In the stories, he is described as sufi saint, Superman, and Tomanurung, a profile that reflects the hybridity of Islamic traditions of South Sulawesi.

Storytelling about Kahar took place in the context of the decentralization and shariahisation of South Sulawesi. In 1999, after thirty years of military rule under the Soeharto regime, Indonesia decentralized itself. The transfer of political power from Jakarta to provincial and district governments intensified the debates in South Sulawesi about the most suitable form for its regional government and identity. Islamist activists reinvented Islam as the identity of South Sulawesi. They proposed to apply shari'a as a strategy to further solidify regional identity as a bulwark against perceptions of domination from the center. The Muslim majority rejected the proposal. While liberal Muslim scholars challenge the formalization initiative through scriptural argumentation, the ordinary Muslims challenge the formalization through storytelling and rituals.

In this article, I explore the use of storytelling by the Muslims of South Sulawesi to confront the shari'a initiative in the province. I draw attention to the use of "story- telling" as a non-analytical form of human communication to further our understanding of Muslims' responses to the formalization of Islamic law. To date, this relationship has been analyzed from the perspective of "scriptural reasoning" or analytical religious discourses. Bowen (2003), Hefner (2007; 2000), Eickelman (2002) and Asad (1989) have described Islam as "discursive tradition", a tradition that relies heavily on analytical discursive argumentation in the public sphere, at the expense of non-analytical forms of human communication such as storytelling. I argue that storytelling about Kahar Muzakkar is a social practice that emerged in response to specific conditions in contemporary South Sulawesi.

While some might argue that storytelling is an ambiguous and subjective form of human communication that lacks rational structures and the reflexivity needed to communicate in the public sphere, I argue (Alimi 2012; 2014b) that storytelling can be an effective means to directly confront the formalization of shari'a and to express local versions of Islam. Certain readings of Islamic law are not free from political interest (Powers 1986), neither is Islamic storytelling (Powers 2010). The investigation of the political, legal, cultural and social factors that lie behind the Islamic narratives allows us to understand the function of the narratives (Power 2010). The function of storytelling about Kahar in South Sulawesi is both to reject shari'a formalization and to reaffirm the hybrid local Islamic traditions, that are threatened by shari'a formalization.

\section{STORYTELLING AND DISCUR- SIVE ARGUMENTATION}

Whereas Bowen identified the Muslims of Sumatra as Muslims through discourse, I identify the Muslims of South Sulawesi as Muslims through storytelling. I use the phrase "Muslims through storytelling" to highlight the different ways of being Muslim, in this case, the use of storytelling in religious life. Discursive argumentation identifies a set of "analytical" strategies used to elucidate aspects of Muslim life through logical 
forms of argumentation. My discussion of scriptural reasoning was inspired by fieldwork conducted in Western Indonesia, particularly Java and Sumatra, where religious debates (notably the interpretation of sharia) are increasingly common. Bowen (1993: 8) uses the term to refer to "the field of debate and discussion in which participants construct discursive linkages to texts, phrases, and ideas held to be part of the universal tradition of Islam". In his influential book, Muslims through Discourse, Bowen (1993:8) analyzes debates, arguments, commentaries, and speeches, all analytical and reflexive forms of human communication. He argues that Muslims attempt to define the norms of public life through "repertoires of reasoning" such as adat (local customs), scripture, and global concepts such as democracy, human rights, and gender equality (Bowen 2003: 5).

The importance of scriptural argumentation in Muslim societies has been highlighted by Asad (1986), Hefner (2000), Eickelman (2004), Didier (2004), Soares (2004), Salvatore (2004), Zaman (2007) and Zeghal (2007). Talal Asad (1986: 14) described scriptural argumentation as "discursive tradition".

\begin{abstract}
A tradition essentially consists of discourses that seek to instruct practitioners regarding the correct form and purpose of a given practice that, precisely because it is established, has a history. These discourses relate conceptually to a past (when the practice was instituted, and from which the knowledge of its points and proper performances has been transmitted) and a future (how the point of that practice can be best secured in the short or long term, or why it should be modified or abandoned), through a present (how it is linked to other practices, institutions and social conditions). An Islamic discursive tradition is simply a tradition of Muslim discourse that addresses itself to conceptions of the Islamic past and future with reference to a particular Islamic practice in the present.
\end{abstract}

I call the practice of using discursive references "to instruct practitioners regar- ding the correct form of a given practice" (Asad 1984: 14) as "referencing", the intellectual effort to justify a practice by referring to the Quran, Hadith or Islamic traditions to justify a practice. Asad correctly points to the centrality of discursive argumentation in the contemporary Islamic world, ${ }^{1}$ but by reducing Islam to discursive reasoning he limits our ability to understand the nuances of Islamic life. The importance of scriptural reasoning is a new development, produced by particular developments in Islamic history since the late eighteenth century, especially the rise of Wahhabism. ${ }^{2}$ Scriptural reasoning is the public transcript of Islam (Bowen 2003). But there are many ways for Muslims to express themselves in the public sphere. For example, Muslims in South Sulawesi use storytelling and rituals (Alimi 2012; 2014b) to engage shari'a in the public sphere. Outside South Sulawesi, for example, in Sumatera, where rituals and storytelling are not as intense as in South Sulawesi, Muslims, as demonstrated by Bowen (1993, 2003), largely use scriptural argumentation.

The importance of scriptural argumentation in contemporary Muslim society should not blind us to the use of non-argumentative forms of rationality, including storytelling, rituals and other forms of human communication. The trivialization of storytelling and other non-analytical forms of human communication by liberal Muslims in Indonesia impoverishes our understanding of the responses of ordinary Muslims to the formalization of Islamic law. Though ordinary Muslims largely express agreement with the implementation of shari'a, through storytelling, rituals and everyday life, they confront shariahisation.

The reluctance to acknowledge storytelling as a rational form of human com-

1 The importance of discursive argumentation in contemporary Muslim life becomes the basis for Hooker and Hefner in describing Islam as "theology in legal form" (Hooker 2008) and a "religion of commentary" (Hefner 2007).

2 Wahhabism is a form of Islam campaigned by the Saudi Arabians that emphasized on religious textuality and authenticity, refuting other influences from the non-Arab world. 
munication derives from a mindset that storytelling is subjective and irrational. Jurgen Habermas (1987: 10) argues that the public sphere ideally should be based on "the force of argumentative speech", analytical and reflexive forms of human interaction, which he calls "communicative rationality". He contrasts communicative rationality with myth. Myths "are far from making possible rational orientations of action in our sense" (Habermas 1987: 44). Mythical worldviews, he explains, lack rational structures needed in academic conversation. Consequently, storytelling could not be used for rational argumentation due to "the insufficient differentiation among fundamental attitudes to the objective, social, and subjective worlds; and the lack of reflexivity in worldviews that cannot be identified as worldviews, a cultural tradition" (Habermas 1987: 52). By contrast, he identifies communicative rationality as the ideal speech situation "devoid of all constraints. All interlocutors are equally entitled to make assertions, raise questions, and/or provide justifications for their positions. And all express their true intentions" (Habermas 1987: 52).

However, Canavan (2011), Cohen (2007), Vandendorpe (2011), McClellan (2011), Krieger (2010), Nicholas and Kline (2010), Samuel and Thomson (1990), and Skeiker (2010) all emphasize the value of myth and storytelling as form of logical thinking in contemporary society. For example, Vandendorpe (2011) argues that storytelling responds to societal and psychological needs. McClellan (2011) argues that vernacular narratives often operate in opposition to formal definitions put forward in official rhetoric about a particular community. Based on his study of the logical and narrative thinking of Jewish rabbis, Krieger (2011) emphasizes that both logical and narrative thinking are essential and interrelated modes of cognitive functioning. He demonstrates that storytelling can have a place in legal reasoning by illustrating how rabbinic narratives reflect the legal rulings of the rabbis. Similarly, Nicolas and Kline (2010) demonstrate how ghost stories help make sense of the tension between tra- ditional mysticism and contemporary logocentrism and, at the same time, perpetuate an ongoing hegemonic masculine-feminine dichotomy.

Powers (2010) also discusses the importance of storytelling among Muslim communities. Though the period he studied is the end of ninth century, but his conclusion is relevant for us living in the twenty first century. Powers (2010) argues that storytelling has particular meaning, and to understand its meaning, one must attempt to expose the meaning of the story that lies immediately below the smooth linguistic surface of the narrative. Powers (2010:129) gives nuances to Charles Pellat's thesis, which represents a common approach to history: "the task of scholarship is to disentangle fact from fiction in the Islamic sources and so reach the kernel of historical truth which they undoubtedly have." Powers (2010) is interested not only in the factuality of the stories, but also in the meaning and significance of the stories. The stories might be not real, but the force and significance they give in people's lives are real. They express reality and are not reducible to empirical prepositions. As Cohen (1997: 212) argues, "Once assertions about the past enter deeply into people's minds (and hearts), they acquire a truth of their own. At the very least, such assertions are true statements about what people believe and therefore, must occupy a central place in any history of human consciousness." Cohen (1997) invites us to see storytelling as essentially to do with symbols. Symbols, as Bellah describes, are non-objective and "express the feelings, values, and hopes of subjects, or which organize and regulate the flow of interaction between subjects and objects, or which attempt to sum up the whole subject-object complex, or even to point to the context or ground of that whole. These symbols too express reality" (Bellah 1970: 93).

\section{KAHAR MUZAKKAR AND DARUL ISLAM}

For Muslims in South Sulawesi, Kahar Muzakkar is an icon of the shari'a state and lo- 
cal pride. He is a symbol of courage, a warrior who defended the dignity (sirri) of Bugis and Makassar. Born in Luwu, on 24 March 1921, the young Kahar was known as Ladommeng, which means "cardplay hero", a testament to his skill in this activity. The young Kahar was smart, diligent, and rebellious. As a teenager, he demonstrated an egalitarian vision of society. He refused to comply with the sharp dichotomies that divided his society, master (puang and karaeng) versus slave (ata) and high rank versus low rank. In his eyes, all people are the same.

Kahar began his career as a nationalist soldier. He guarded Soedirman and Soekarno, two founders of the Republic of Indonesia, fought for Indonesian independence, and participated in the war against the First and Second Dutch Military Aggressions in Yogyakarta in 1947 and 1948. He was also involved in the crackdown on the communist rebellion in Madiun, East Java in September 1948. ${ }^{3}$ Disappointed by Soekarno's decision to "rationalize" 4 the army and also his inclination towards communism, on 20 January 1952, Kahar led the former guerrilla armies of South and Southeast Sulawesi into the forest of South Sulawesi where he established Darul Islam (an Islamic state in Eastern Indonesia) and implemented Islamic law.

Kahar received massive support, in the form of logistics, protection and followers, from Lompobatang in the south to Latimojong in the north. This influence in South Sulawesi was acknowledged by Colonel Abdul Haris Nasution (cited in Gonggong 1992: 1), an influential army official: "The development of Darul Islam from an underground movement into a guerrilla movement, with the capacity to strike and move from one place to another, indicates that DI had large armies and widespread civilian support." In Jakarta's official discourse, Kahar was a rebel. The official report on the Indonesian army website explained that Kahar

3 Rakyat Merdeka, Sabtu, 1 April 2006, Kahar Muzakkar Masih Hidup

4 Rationalization is the effort of the Jakarta government to recruit guerillas who have formal education into the army. Men who do not have school certificates are not accepted into the army. "expected that the former guerrilla armies in South Sulawesi would be accepted as soldiers in APRIS (Angkatan Perang Republik Indonesia Serikat / The Army of the United Republic of Indonesia). However, the expectation was disappointed when the Government demobilized some of the APRIS forces. According to Harvey, Kahar was not a rebel. He notes (1974:3) that South Sulawesi

was not recognized as part of the de facto Republic of Indonesia, nor were many of its pemuda (youth) included in the regular army of the Republic, which was not based on the PETA, a Japanese sponsored youth corps which did not exist in South Sulawesi. Further, levels of education in South Sulawesi were low-and levels of illiteracy high-thus there were few pemuda from the area who could meet the strict qualifications of a professional army.

Kahar argued that the rationalization program adopted by the central government failed to recognize the contribution of his followers, who had struggled for the nation's independence and sacrificed their lives (Harvey 1974; Gonggong 1992). The injustice reportedly had affected Kahar's sense of sirri, the idea that the betrayal of one's dignity must be repaid even at the expense of one's life (Gonggong 1992). His courage and promise to restore self-dignity make Kahar Muzakkar an appealing figure who continues to attract the sympathy of South Sulawesi Muslims, rural and urban. He is a symbol of justice, courage and self-dignity.

\section{MAKALUA CHARTER, THE CON- STITUTION OF DARUL ISLAM}

Kahar mobilized a guerrilla war against Jakarta in the forest of South Sulawesi. In the forest, he and his ministers managed the Islamic state and implemented sharia law. Kahar abducted religious leaders and forced them to live with him so that they could make recommendations on the implementation of Islamic law in the forest. Men and women who lived in the forest with Kahar told me that he strictly enforced Islamic law, including criminal law. For example, Nurhayati, who was abducted by Kahar with her 
father, told me that her mother witnessed people whose hands were cut off or who were stoned to death. "That experience became a trauma for my mother. I do not remember many of punishments in the forest because I was only five." Kahar's version of Islamic law was legalised in the Makalua Charter, the constitution of Darul Islam. In this document, Kahar not only regulated the application of Islamic law, but also banned sacred regalia, the use of titles to indicate social status, and sufi practices that were widespread in South Sulawesi.

Social status plays a key role in structuring social life in South Sulawesi. The Bugis Makassar has a keen sense of social status and the need to display it. Typically, Muslims display social status through hajj caps, female hajj head-coverings, house building, and wedding rituals (Robinson 1989; Millar 1986; Reid 200o). Kahar Muzakkar wanted to change this culture of stratification by promoting an egalitarian vision of Islam. For example, he prohibited the pilgrimage cap (topi haji). According to Haritsah, who followed his religious teacher to the forest and lived with Kahar: "A haji was detained by Kahar because of his insistence on wearing the pilgrimage cap, which symbolizes high status and piety. But the haji refused to take off his pilgrimage cap and he confronted Kahar. 'This hajj cap will only be taken off with my head". Kahar's attempts to eliminate regalia, sufi orders, and symbols of social status are formalized in the Makalua Charter. Below are some examples of the chapters in the constitution:

Chapter 15. All forms of fanatic feudalism, sufi orders, paganism and superstition should be eliminated.

Chapter 16. Any revolutionary Muslim and resident in the eastern part of Indonesia who intentionally or unintentionally uses titles of pride and feudalism, such as ibu bapa, ana opu, puang, karaeng, petta, andi, daeng, haji, laode, gede take, gede bagus, eanggu, bohoki, saijed, adik and the other feudal titles should be punished.

Chapter 16. Any descendant of noble people who ignores and does not resist fe- udalistic titles should be punished.

Chapter 17. Any element that uses and believes in the power of regalia, such as stone, kris and others, should be punished.

Chapter 18. Any member of the army, police, government and people who ignores prayers five times should be punished.

Kahar had reached a point where he challenged the local culture and the Islamic traditions of South Sulawesi. His intolerance towards local expressions of Islam is the key reason why the people of South Sulawesi left Kahar Muzakkar and his shari'a (Hamid 1985).

\section{KAHAR MUZAKKAR IN STATE DISCOURSES}

After thirteen years on the run, Kahar was shot dead on 3 February 1965, on the bank of Lasolo River, by Siliwangi government soldiers of Yon 330 Kujang I. The attack terminated Kahar's Islamic state and the implementation of shari'a in the forest. Sadeli, a Siliwangi soldier, recalled the attack. The night before, around nineteen Siliwangi soldiers had identified Kahar's camp in a forest. In the camp, there were around one hundred and twenty civilians, twenty armed guards and Kahar himself. Kahar was easily identified from a radio which was always with him. According to Sadeli, at six o'clock in the morning, Siliwangi soldiers pinned down Kahar and his group with a 15-minute exchange of fire. "I was hiding in a tree when I saw a guerrilla fighter lifting his automatic machine gun. Kahar Muzakkar was behind him. I didn't know why Kahar came to the tree behind which I was hiding. When he was close, I shot him three times right in his heart." 5

Kahar's body was transported by military helicopter to the military-owned Pelamonia Hospital, in the heart of Makassar, the capital city of South Sulawesi. To confirm his death, his body was flown to Jakarta to be seen by Soekarno, the first president of Indonesia. Soekarno insisted on seeing

5 http://www.pikiran-rakyat.com/cetak/0403/05/hikmah/lainnya01.htm 
with his own eyes the corpse of his former guardian (Tangke 2009). The drama ended there. There is no grave or stone that marks Kahar's resting place. The death of Kahar Muzakkar halted Darul Islam.

After the Soeharto military regime had collapsed and power had been decentralized, many different versions of the story emerged. According to one version, prior to the attack, General Jusuf, the commander, met Kahar and told him to leave the forest. After that, Kahar disappeared. In this version, the person shot was someone who looked like Kahar. In another version, Kahar was invulnerable to bullets, like Superman. These stories suggest that the collapse of the Soeharto regime marked the collapse of its national imagination about Kahar. However, the invocation of Kahar does not point to South Sulawesi's renewed support for regionalism against Jakarta (as was the case during 1950 and 196os) or to the support of South Sulawesi Muslims for the type of sharia promoted by the Islamists. Rather, the stories about Kahar and his form of Islam challenge agendas that seek to formalize shari'a, and they offer a different understanding of the relationship between sharia, politics and Islamic cultural traditions in South Sulawesi.

\section{KAHAR MUZAKKAR IN STORY- TELLING}

During my fieldwork in 2006 and 2007, many people in South Sulawesi told me that Kahar Muzakkar is still alive. His reincarnation in storytelling takes at least four forms: (i) Kahar as a saint, (ii) Kahar as Superman, (iii) Kahar as tomanurung and (iv) Kahar as someone who can enter into a woman's dream, have sex with her, and impregnate her. Ironically, these four "types" represent the anti-thesis of the sort of textual interpretation that Kahar Muzakkar advocated. Kahar was a modernist Muslim who wanted to implement a textual form of shari'a. He rejected Islamic mysticism, irrational belief and heresy. Historians largely ignore these stories because they are fictional narratives. But the use of the story to defend the public sphere and indigenous expressions of Islam indicates that such assertions are true statements about what people believe.

One of the most striking descriptions of Kahar is that he is a playboy who can enter a woman's dream and have sex with her. This story is documented in Fajar (17/1/2007), the most widely-read local newspaper in South Sulawesi, with a readership of approximately $74 \%$ of the population, according to its editors. The newspaper published an article on the confession of a twenty-year-old woman, Farida, a resident of Bone, a city $50 \mathrm{~km}$ from Makassar. She said that she became pregnant after dreaming that she slept with a man who resembled Kahar Muzakkar: "The man had a big hairy body", Farida said. This identification fits the popular description of Kahar. Farida told the media that the dream occured on 12 December 2005, and that she gave birth to a baby boy on December 9, 2006, with the help of a traditional medical practitioner. The story is odd because Kahar is a religious person, and engaging in an extramarital sexual relationship is a big sin, even in a dream. Kahar and his followers would reject any such allegation of extramarital sex.

In the second story type Kahar is still alive and wandering as a wise religious teacher. I first encountered this story at my field site, Kindang, Bulukumba, where I met a female student from Bone who was visiting her uncle. She told me that her brother had met Kahar Muzakkar in a mosque in Bone. After the noon prayer, her brother told her that he had seen an old man dressed in clean white clothing who looked tired. He let this man rest at his little accommodation not far from the mosque. After three hours, the old man left. Her brother believed that this man was Kahar Muzakkar. I heard similar stories in Makassar, Pangkep and Enrekang.

People disagree over whether Kahar Muzakkar is still alive or not. One day, after the Ramadhan morning prayer, my colleague, a lecturer at the Alauddin Islamic State University (UIN) Makassar, challenged his audience. This lecturer (who claimed to have interviewed more than 200 veterans of the Darul Islam rebellion for his doctoral thesis) 
argued that Kahar was dead. However, the majority of the audience insisted that Kahar is still alive and that someone else had been killed in the Lasolo River. "Kahar has a sacred power that makes him immune to bullets", insisted one participant. My colleague replied that these stories are superstitions. As rational men, he continued, we should not believe in unscientific rumors. Islam, he added, is a rational religion and, both rationality and egalitarianism are what Kahar envisioned. When the discussion ended at sunset, many people were dissatisfied and continued the debate in the mosque.

In Pangkep, approximately two hours from Makassar, Puang Rahima told me why Kahar is still alive:

The person who was shot dead by the armies was not Kahar but somebody else who resembled him. When he was still a child, his father was told by a mysterious old person, it is not known where he was from or where he was going to, that he should take care of his son, because one day, he would be a leader in South Sulawesi. After that meeting, the father always insisted that his wife should watch his son carefully. One afternoon, while on his way home from the garden, he found that La Domeng [Kahar] was playing in the village yard, with his peers, without the presence of his beloved mother. He rushed into his house not far from the yard. Just as he was about to scold his wife, he discovered to his surprise that little Ladommeng was playing with his mother. His mother said that Ladommeng had been playing with her in the house (Interview with Puang Rahima Pangkep).

Puang Rahima concluded that there are two Kahars: one, an ordinary human being and the other, an extraordinary human. The human being was shot dead in Lasolo River.

In the third story type, Kahar is a saint. In Enrekang, approximately four hours north of Makassar, Kahar was also said to be alive and serving as a high ranking spiritual saint. "Kahar now is the leader for all saints known in the Islamic world [in the Islamic tradition, Wali Qutb]. These saints organize weekly meetings at Bambapuang, the mountain in the northernmost part of South Sulawesi, and I usually serve as an assistant in the meeting", Puang Yunus told me.

In the fourth story type, Kahar is Tomanurung, literally "one who descends". Tomanurung is a stranger king: a stranger arrives (suddenly), impresses people with his sacred power, and is crowned as a king who will restore order (Sahlin 1981). In the past, in South Sulawesi, the Tomanurung concept was used to justify the divine origin of the royal family and its authority over other groups. In contemporary South Sulawesi, the Tomanurung concept is sacralised in La Galigo, the local Mahabarata epic legends about the origin of rulers in South Sulawesi.

What is intriguing about the four types of Kahar stories is the striking difference between the Kahar of storytelling and the Kahar of real life. The reference to Kahar's sacred powers, extra-marital sexual relations, and status as a spiritual saint clash with the modernist religious teachings he embraced. These attributes and actions also clash with the principles that he formalized in the Makalua Charter.

\section{BRINGING ISLAMIC LAW TO THE CITY}

After the collapse of the Soeharto regime in 1998, Islamists attempted to revive the shari'a by formalizing shari'a law in the province. They wanted to carry the shari'a from the forest to the city. The idea of formalization was promoted by KPPSI (the Committee for the Implementation of Shari'a), an Islamist organization with a special mission to implement Islamic law in South Sulawesi. Like Kahar, KPPSI holds that Islamic legal teachings should be implemented in every aspect of life (Alimi 2014a). The relation between KPPSI and Kahar is genealogical and ideological. The chair of KPPSI is Kahar Muzakkar's son: Azis Kahar Muzakkar. Unlike his father, the son pursues an Islamic state through constitutional laws and peaceful means. As for the ideological connection, Kahar's vision of shari'a is central to KPPSI's imagination. Instead of a "rebel", 
Kahar is regarded by KPPSI as a pejuang (warrior), as stated in a recommendation of the Second Congress of KPSSI (29 -31 December 2001): "Darul Islam under the leadership of Colonel Abdul Kahar Muzakkar, a fighter from South Sulawesi, conducted jihad to enforce Islamic Law in opposition to the deletion of seven words from the Jakarta Charter and the influence of communism in South Sulawesi at the dawn of 1951." KPPSI inherited Kahar's belief in the superiority of Islam over other ideologies, as expressed in Kahar's Catatan Batin (Inner Notes):

Liberals are intoxicated and they frighten humans with nuclear weapons, the product of human intelligence.

Communists are crazy, and drag humans into the world of animal relationships and nuclear threat.

Nationalists orchestrate the greedy spirits of nationalism, throwing religion outside the state, and making people fight each other without end.

Non-Muslims who refuse the oneness of God, such as Jews, Christians, Hindus, Buddhists and so on, are confused because they believe in many gods. This makes them live in the world of doubt: doubt over their religion, doubt over human spirits and doubt over the gods and statues they worship (Muzakkar 1955: 140).

The superiority of Islam is echoed in KPPSI's arguments for the implementation of shari'a in South Sulawesi. As explained by Azwar Hasan (2005: 150), the secretary general of KPPSI:

KPPSI believes that Islamic Law is the solution to the multi-dimensional crises that have afflicted Indonesia. Since independence, Indonesia has introduced secular ideologies: Developmentalism entwined with capitalism under Soekarno, capitalism under Soeharto and nationalism under Habibie, Abdurrahman Wahid and Megawati. None of these makes Indonesia better. At the same time, Islam was not given an opportunity to regulate the nation except in the area of material benefits, such as alms (zakat), charity and pilgrimage.
By its second year, KPPSI had built a network of politicians, bureaucrats and civilians in South Sulawesi to support the formalization of shari'a. In every district of South Sulawesi, KPPSI opened a branch office and appointed the district head as its local leader. KPPSI also organized annual congresses and paramilitary forces to increase its influence. Most politicians and bureaucrats identified with the Islamist movement and used it as vehicle to be appointed as district head or to attain a high position in the government.

KPPSI regularly organized public events. During the reformasi period, the popularity of KPPSI exceeded that of some traditional political parties, including the Golkar party which was strong in South Sulawesi. Many politicians stated that they supported the implementation of shariat the provincial level. Of course, this was solely lip service. KPPSI became an effective political machine, though it is not a political party. Many of its officials became chairmen of government bodies, and its members participated in district elections. To recruit members, they organized public rallies, media conferences and annual congresses. As a consequence of KPPSI's activities, shari'a discourse has become pervasive in South Sulawesi.

The ubiquity of sharia discourses has not resulted in shari'a legislation at the provincial level, however. The provincial government and parliament repeatedly argued that they should use acceptable constitutional mechanisms since such legislation needs approval from Jakarta. Shari'a in Sulawesi did not become a government policy until the government of Bulukumba, a district in the southern part of South Sulawesi, implemented some aspects of shari'a. The government of Bulukumba legislated four by-laws in 1999: one on Quranic literacy, one on Muslim dress, one on the distribution of alcoholic beverages, and one on charity and endowments (wakaf). The Quranic literacy by-law stipulates that every bride and groom should be able to read the Quran as a requirement for getting married. The Muslim clothing by-law stipulates that every fe- 
male civil servant and student should wear a headcover. Civil servants also should pay a certain amount of alms from their salary.

Following the legislation of these four bylaws, Bulukumba was divided into those who were for and against the formalization of Islamic law. The liberal Muslims, represented by LAPAR, a non-governmental organization composed of Islamic students, challenged formalization. They presented arguments drawn from the Quran, hadith and other Islamic sources for why sharia should not be formalized. For LAPAR, the essence of Islamic law is justice, equality, tolerance, and welfare. The LAPAR spokesperson told me that the government can implement sharia by providing justice, equality, and good education to the people. There is no need for shari'a law to be formalized. Thus, liberal Muslims challenged the formalization of religious law by using scriptural argumentation. By contrast, ordinary Muslims challenged shariahisation by using storytelling and rituals.

\section{AGAINST SHARI'AHISATION}

Storytelling about Kahar Muzakkar should not be understood in literal terms. At first sight, the stories appear to celebrate Kahar, his resoluteness, his Islamic identity, and the promise to restore sirri. But the stories are inconsistent with Kahar's Islamist vision of society and sharia. This challenge to Islamic law through storytelling was strengthened by the explicit rejection of Kahar's interpretation of Islamic law and the retelling of the bitterness during the rebellion by those who were directly affected by the rebellion. Among those who suffered during the 1950 s and 1960 s were traditional adat communities such as bissu in Segeri (the pre-Islamic transgender Bugis priests, who reportedly have the power to connect the human world and the divine world) and Kajang in Bulukumba (a traditional community in the mountain of Kajang in the southern part of South Sulawesi), sufi groups and traditional Muslims in rural areas.

\section{RITUAL COMMUNITIES AND SUFI GROUPS}

During the Darul Islam rebellion, traditional communities such as as bissu and Kajang experienced hard times. They were regarded as musyrik (polytheists). Bissu suffered the most because their transgender identity do not conform with traditional gender norms and the pre-Islamic rituals they practice. Many of its members in Bone, Soppeng, and Pangkep were killed, and their shrines were demolished. Despite the suffering, this group still regards Kahar as a kindhearted man who bears no responsibility for the calamities. During the turbulent period of reformasi, many bissu described Kahar as a good person, a hero who did not participate in the violence against them during the rebellion. The destruction was wrought by low-ranking soldiers. "Kahar himself was a good man. He did not challenge or kill bissu. The atrocities were committed by his soldiers who were not disciplined and did not listen to their commanders," said Puang Matowa Bissu Saidi, the leader of the bissu (Interview July 4, 2006).

Kajang Muslims were persecuted during the rebellion, and they created "dompe", a special paramilitary to defend their interests. However, in 2007 when Azis Kahar Muzakkar-the son of Kahar Muzakkar and the leader of KPPSI-visited the Kajang Muslim community, the mother of the group leader identified him as "having the face of the prophet, which is not surprising as he is the son of Kahar Muzakkar". The bissu and Kajang community tried to defeat Kahar by embracing him. They describe him with good attributes because they wanted to show that they accept Islam. They are part of Islamic community in South Sulawesi. Thus, by embracing Kahar, the people in these communities thought that they would be demonstrating their piety, thereby reducing the level of persecution.

While ritual communities such as Bissu and Kajang tend to accept shari'a as a defensive strategy, some Islamic groups have confidently challenged Kahar's shari'a. This is exemplified by the Khalwatiah sufi order, 
an influential Muslim group in South Sulawesi. The Khalwatiah challenged the Darul Islam because the group has a strong base in South Sulawesi, and it has many religious authorities who mastered the arts of scriptural argumentation. Kahar regarded sufi practices as dangerous to Islamic belief. However, because of the repression and violence during the Darul Islam rebellion, this sufi order became widespread across South Sulawesi. Many believed that the group could provide mantras for self-defense in a cataclysmic situation. Puang Malke, a prominent Khalwatiah teacher, said that the period was a test for Syaikh Muhammad Amin, the Khalwatiah leader at that time. Kahar's men tried to force Syaikh Amin to join Kahar's Islamic republic in the forest and serve Kahar as a qadhi (judge) on religious matters. Kahar kidnapped several clerics, but he failed to kidnap Syaikh Amin. Facing the soldiers who wanted to kidnap him, Syaikh Amin said: "I don't want to leave this place but if you insist on taking me, it is OK. Being here or there does not make any difference at all. It is still me. I will go if this boat can take me." This statement was related to me by the son of Syaikh Muhammad Amin. The boat anchored in the Maros River would not move; but as soon as Syaikh left the boat, it started. Then it stopped again when the sheikh got on the boat. The mechanical failure occurred several times, frightening the soldiers, who cancelled their plan to take him to the forest (Interview 7 July 2007). The spiritual leaders of this Sufi order cite the story of their repression during the rebellion and the success of their leaders in overcoming oppression as evidence of their excellent spiritual rank.

\section{FOR THOSE WHO HAVE BEEN IN THE FOREST}

I met people who lived in the forest with Kahar during the rebellion. Some of these people followed fathers (e.g. Nurhayati and Haji Sanirah) who had been kidnapped by the army of Kahar Muzakkar. Others (e.g. Kiai Haritsah, who later became a well-known cleric in Makassar) follo- wed a teacher. I asked these people about their experience in the forest and what they thought about the proposed sharia initiative in South Sulawesi. They largely agree that Kahar's vision of an Islamic state is irrelevant and dangerous. Nurhayati followed her father, Abdurrahman Matemmeng, a wellknown cleric who was kidnapped by Kahar's army, together with other religious leaders such as Abdurrahman Ambo Dalle and Kali Sidenreng. She told me about her mother's bitter experiences living in the forest during the rebellion. As mentioned, her mother is still traumatized by the application of Islamic law to thieves (amputation) and adulterers (stoning to death).

Haji Sanirah told me a similar story. Following her father, she had to move from one place to another to run from the Indonesian army. Her father followed Kahar because he wanted to defend the dignity of South Sulawesi. "In the forest, food was scarce. People ate ground up stone and drank water from rivers." Haji Sanirah recalled that paying more than 250 rupiah $^{6}$ in spending money (uang belanja) at a wedding ritual was not allowed because it signified social status, and in Garuntungan, people were not allowed to eat horse meat, the favorite meat at a wedding feast. "However, my father usually slaughtered a horse despite the warning of the guerrilla army", said Haji Sanirah.

Kiai Harisah followed his teacher, Gurutta Abdurrahman Ambo Dalle, a respected religious leader in South Sulawesi, into the forest. Ambo Dalle was abducted after he gave a religious speech in Maros. However, he continued to give lessons in the forest under a house, a tree, or a musalla (prayer site). One of his followers was young Haritsah, who was still in his teens. Haritsah carried his teacher's bag and followed the lessons despite the difficulty of living between fear and bullets. According Haritsah, Kahar's interpretation the polygamy verse in the Quran provoked the resentment of the religious leaders around him. The Quran says: "If you fear that you cannot be just to fatherless orphans, then marry those whom you

6 This amount is equivalent to approximately 20 dollars. Currently one US dollar is approximately Rp. 13.000 . 
see fit from the women, two, and three, and four. But if you fear you will not be fair then only one, or whom you already have contract with. So that you do not commit injustice and suffer hardship (Quran 4:3, translation of Edip Yuksel and Layth Saleh al-Shaiban 2007:91)". According to mainstream ulama in Indonesia, polygamy is permitted. Specifically, men are "allowed" to marry up to four women at a time, provided that certain conditions are met. Kahar, following his religious teacher in Java, interpreted the verse as allowing nine wives, instead of four.

\section{MEMORY IN THE BATTLE- GROUND}

Fierce battles took place between Kahar's guerrilla army and the Indonesian military in Kindang, my field site. Kindang's thick forests and mountains provided secure shelter for the rebels. The Indonesian army made frequent sweeps through this region and built barracks nearby. In those days, jets roared in the sky and frequently sprayed the ground with hundreds of bullets. One day, a man was killed by a deluge of bullets from the sky. This man, whose identity unknown, was buried near the village road. To this day the gravesite (in modern Tamaona) is a nogo zone and reportedly a "frightening place", especially amongst children in the village. Some people also believe that a baby should not pass this grave until he or she is forty days old.

Many people remember those events as if they happened yesterday. Haji Code, who in 2006 was entering his ninetieth year, said that the guerrillas demanded the verbal articulation of syahadat, ${ }^{7}$ despite the fact that he, and many other people in the village, already had inner conviction (syahadat batin) - a form of syahadat that is not verbalized. Haji Code pointed to his chest as he uttered the formula. People who were unable to recite syahadat were beaten with rifle butts or bamboo. For Haji Code, the Kahar

$7 \quad$ Syahadat is the Muslim declaration that "there is no God but Allah and Muhammad is the messenger of Allah." This statement marks someone's entrance into the Islamic faith. movement imposed its own form of verbal and formal religious expressions, expressions that he did not believe in.

Haji Code and his family fled when they heard that the guerrilla forces or the Indonesian armies were approaching. The guerrillas usually came to the village to ask for rice. If the villagers refused, the guerrillas would burn down the houses. If the Indonesian forces knew that the villagers were giving rice to the guerrillas, they too would burn down the houses. To avoid this dilemma, many villagers fled to forest-which was not yet controlled by either force-after hanging rice in front of their houses. When the guerrillas or the army had gone, they would return.

Many people told me that a visit to town could result in death. Haji Code said that the Indonesian army or the guerrillas might suspect them of being enemy spies. Many people carried two sets of ID papers: one from Kahar and one from the army. Haji Code described that period as a bitter time. He does not want his children and granddaughters to experience that bitterness. "It is enough to be part of my life in the past," said Haji Code. "Young people who promote the current shari'a were born only yesterday. They did not know the difficulties of living between bullets. They didn't know the difficulties of living in continuous fear".

\section{STORYTELLING AS A CHAL- LENGE TO SHARI'A}

Storytelling about Kahar directly and effectively challenges the formalization of shari'a in South Sulawesi. Unlike scriptural argumentation, storytelling directly describes the forms, texture and particularity of Islam in South Sulawesi. Telling stories about Kahar at the time of shari'ahisation is like eating noodles when everyone is forced to eat meatballs. It is a direct and gentle way to express resistance. Storytelling spreads faster than discursive Quranic argumentation because it is part of local knowledge and does not need sophisticated religious training. Liberal Muslims who argue against the formalization of Islamic law often face 
strong opposition because they are accused of being anti-sharia. Storytelling allows ordinary Muslims to avoid such accusations. If asked: "Do you agree with the implementation of shari'a in South Sulawesi?" most will answer, "Yes, I agree". But if the question is rephrased as: "Do you want Kahar Muzakkar's interpretation of the shari'a to be applied?" they will say "no". Through storytelling, they resist shari'a formalization.

Storytelling allows ordinary Muslims to use allegory to oppose shari'a formalization. When assessing the utility of allegorical mechanisms such as storytelling, it should be recognized that such stories are not an accurate (fact-based) retelling of the past. Rather, they are a response to the unfolding of new social dynamics at the local and/or national levels. Storytelling about Kahar Muzakkar is more about resistance to shariahisation than about Kahar Muzakkar. Cohen (1997: 238) argues that: "When the past is treated as myth, its meaning is governed to an overwhelming extent by the concerns of the present. As the center of gravity of present concerns shifts, therefore, the meaning of the past necessarily shifts along with it, sometimes to a quite extraordinary degree." Muslims in South Sulawesi circulate stories to defend their locality and locate themselves within the new social circumstances created by radical political and social changes. As Foster (2002) argues, we need myths to help us organize and guide our lives.

\section{ISLAM AND ISLAMIC LAW AS STORYTELLING}

The use of storytelling to engage discussion of shari'a in the public sphere has roots in the representation of Islam and Islamic law as storytelling in South Sulawesi. Through storytelling, Muslims introduce the arrival of a new religion, as exemplified in the story of Sawerigading, a central mythic figure in the La Galigo story. In one of these stories, Sawerigadeng is identified as the "foremost and last" prophet. As the protagonist of the La Galigo cycle, Prophet Muhammad is identified as Sawerigading reborn. The following passage, translated by Pelras (1996:
197) illustrates this:

The news is broadcast that Heaven and the Abyss must be emptied because the Holy Book (al-Furqaan, the Qur'an) and the syahadat (the Islamic declaration statement) were sent down to Earth and humankind. In accordance with the will of the One Lord, Batara Guru and the other heavenly being will move towards the rising sun; Sawerigading and all other beings living in the Abyss will move toward the setting sun. From then on, only angels and genies will inhabit Heaven and the Abyss, and humans will no longer be permitted to worship Patoto' and Paline. ${ }^{8}$ God alone will dwell in the highest sky. Later, Sawerigading's soul will be sent to Mecca and "introduced into a pure womb" to be reborn there.

William Cummings (2002: 155) has documented a different story about the arrival of Islam, the story of garuda's descent in South Sulawesi:

Of this descent of the garuda to Sanrabone, one story tells that Nabi Muhammad made himself into a garuda bird and descended to Sanrabone. Another story says that Gabriel made himself into a garuda bird and was ordered by Allah Ta'ala (may He Be Exalted) to descend to Sanrabone to plant the truths called Islam. This garuda descended to Sanrabone on a Friday when people where coming out from Friday prayer at the mosque. This was in the year 1175 Hijra. The garuda descended on the south side of Lajalajaya in Bantilang Biseang, above a campagaya tree in Sanrabone. That garuda had two heads, a large one on the right, and a small one on the left. All its feathers were covered in Arabic writing. It was there, alighted on a broken campagaya branch, but it kept hovering just a little, touching its claws to a large branch of the campagaya tree. The one who described the garuda was Puang Abdul Gaffar, Daeng Janggog. The one who copied the Arabic letters that were on the garuda's body, he was I Daeng Daeng Ngawong. The one who spoke with the garuda, he was I Johoro Daeng Ngena. The garuda was there from when he came at lururu (lohor, the midday prayer) until af-

\section{Patoto and Paline are the Gods of the} traditional Bugis. 
ter asaraq (asar, the late-afternoon prayer) then he left, flying up. When people went to maghrib prayer (the sunset prayer) he could no longer be seen. This was the coming of the garuda when it was in Sanrabone.

Stories like this integrate Islam into the local imagination. Through these stories, the pious Muslims of South Sulawesi attempt to reconcile the contradictions between Islam and South Sulawesi culture. In times of religious radicalization, they use storytelling to challenge the formalization of religious law in local politics. Of course, storytelling is important for Muslims everywhere. It is a common practice. This importance can be seen in the practice of reading keramat tales (Millie 2004; Arps 1990), widespread in the Islamic world, particularly among the sufi communities.

\section{CONCLUSION}

The Muslims of South Sulawesi engage the public sphere and challenge the formalization of shari'a through storytelling. Through stories, Muslims are able to consolidate their place within new socio-political circumstances. In contrast to scriptural argumentation, which is performed by people who have requisite knowledge of religious discourse, storytelling has broad appeal and can be performed by Muslims with differing levels of doctrinal knowledge. For ordinary Muslims who have not mastered the religious sciences and scriptural reasoning, sharia is a sacred construct that cannot be directly challenged. However, it can be challenged indirectly through storytelling. By reimagining the image of Kahar, Muslims are able to defend indigenous expressions of Islam in South Sulawesi. Failing to include non-analytical forms of human communication in Muslim interaction with shari'a repeats the mistakes of previous scholars (Fauzan 2001; Geertz 1965), who described the Muslims of South Sulawesi as conservative Muslims who were opposed to the syncretic Javanese.

One of the core questions here is, why do people choose storytelling over traditional scriptural reasoning? Based upon his research in China, Cohen (1997) argues that people tend to use storytelling to challenge authoritarianism. Chinese tales about Mao have little to do with what Mao himself said or did. The situation in South Sulawesi differs from that of China, where state surveillance is strong. Although there is no official surveillance, the dynamics in South Sulawesi demonstrate the extent to which "authoritarian tactics" can be deployed by non-state actors such as KPPSI (a paramilitary force) or by the omnipresence of strict religious interpretation. Unable to criticize shari'a through verbal statements, Muslims criticize it through daily practice and storytelling. In China, South Sulawesi and elsewhere, people must express themselves and try to legitimize what they say by using whatever philosophical and/or theological system, which is most appropriate: The Quran, Mao, Foucault, or Kahar. The resilience of Islamic traditions in South Sulawesi has contributed to the collapse of the initiative for implementing sharia. The idea of shari'a formalization, which is doctrinally very close to Salafism (Wahhabism), does not fit with Islamic traditions in South Sulawesi. Moreover, the public is becoming increasingly sophisticated and aware that Islamists use shari'a as a mechanism to achieve certain political interests.

\section{ACKNOWLEDGEMENT}

I thank The Directorate of Higher Education, Indonesia and Semarang State University for making this research and publication possible. I also thank anonymous reviewers for their insightful comments.

\section{REFERENCES}

Alimi, Moh Yasir. 2012. Head-covering to Live By: Cipo'-Cipo', Shari'ah and Women's Experience of Clothing in South Sulawesi' Intersections: Gender and Sexuality in Asia and the Pacific Issue 30, November 2012.

Alimi, Moh Yasir. 2014a. Local Repertoires of Reasoning and The Islamist Movement in PostAuthoritarian Indonesia. Indonesia and the Malay World. Vol. 42 (122): 22-42. DOI:10.108 o/13639811.2014.884315.

Alimi, Moh Yasir. 2014b. Islam as Drama: Wedding 
Rites and the Theatricality of Islam in South Sulawesi. The Asia Pacific Journal of Anthropology. Vol 15 (3): 265-285. DOI:10.1080/14442 213.2014.915875.

Arps, Ben. 1990. Singing the life of Joseph: an all-night reading of Lontar Yusup in Banyuwangi East Java. Indonesia Cricle. 53:34-58.

Asad,Talal. 1986. The Idea of an Anthropology of Islam. Washington DC Centre for Contemporary Arab Studies. Goergetown University.

Bellah, Robert N. 1970. Christianity and symbolic realism. Journal for the Scientific Study of Religion. Vol.9: 89-99.

Bowen, John R. 1993. Muslims through Discourse: Religion and Ritual in Gayo Society. Princeton, NY: Princeton University Press.

Bowen, John R. 2003. Islam, Law and Equality in Indonesia: An Anthropology of Public Reasoning. Cambridge: Cambridge University Press.

Canavan, Anne. 2010. The Southern Tale-Telling Tradition in Daniel Wallace's Big Fish. Storytelling, Self, Society. Vol 7 (2): 128-138. DOI: 10.1080/15505340.2011.561081.

Cohen, Paul A. 1997. History in Three Keys: The Boxers as Event, Experience, and Myth. New York: Columbia University Press

Cumming, William. 2002. Making Blood White: Historical Transformations in Early Modern Makassar. Hawai: University of Hawaii Press.

Didier, Brian J. 2004. When Disputes Turn Public: Heresy, the Common Good and the State in South India. In Public Islam and the Common Good. Ed. A. Salvatore and D. F. Eickelman. Pp. 157-18o. Boston and Leiden: Brill.

Eickelman, Dale F. 2002. Foreword: The Religious Public Sphere in Early Muslim Societies. In The Public Sphere in Muslim Societies. Ed. M. Hoexter, S. N. Eisenstadt, and N. Levtzion. Pp. 1-8. New York: State University of New York Press.

Foster 2002. Womb with a View. In review of Joseph Cambell's Myths to Live By. Url. http://www. amazon.com/Myths-Live-Joseph-Campbell/ $\mathrm{dp} / 0140194614$.

Geertz, Clifford. 1965. Islam Observed: Religious Development in Morocco and Indonesia. Chicago: The University of Chicago Press.

Gonggong, Anhar. 1982. Abdul Qahhar Mudzakkar: Dari Patriot Hingga Pemberontak. Jakarta: Gramedia.

Habermas, Jurgen. 1987.The Theory of Communicative Action. Boston: Beacon. Press.

Hamid, Abu. 1985. Manusia Bugis-Makassar: Satu Tinjauan Histories Terhadap Tingkah Laku dan Pandangan Hidup Manusia Bugis Makassar. Jakarta: Intildayu.

Harvey, Barbara S. 1974. Tradition, Islam and Rebellion: South Sulawesi 1950-1965. Ph.D Dissertation. Cornell University.

Hasan, Azwar. 2005. Quo Vadis KPPS. In Ikhtiar Menuju Darussalam. Ed. H. M. Sirajuddin and I. Yahya. Pp. 146-150. Jakarta: PustakaAr-
Rayhan.

Hefner, Robert W. 20oo. Civil Islam: Muslims and Democratization in Indonesia. Princeton: Princeton University Press.

Hefner, Robert W. 2007. Introduction. In Schooling Islam: The Culture and Politics of Modern Muslim Education. Ed. R. W. Hefner and Q. M. Zaman. Pp. 1-39. Princeton and Oxford: Princeton University Press.

Hooker, M. Barry. 2008. Indonesian Syariah: Defining a National School of Islamic Law. Singapore: ISEAS Publishing.

Katu, Samiang. 2001. Pasang Ri Kajang: Kajiant entang Akomodasi Islam dengan Budaya Lokal di Sulawesi Selatan. Makassar: PPIM IAIN Alaudin.

Krieger, Stefan H. 2010. The Place of Storytelling in Legal Reasoning: Abraham Joshua Heschel's Torah min Hashamayim. Storytelling, Self, Society. Vol 6 (3): 169-193 DOI: 10.1080/15505340.2010.504400.

Mattalioe, Bahar. 1994. Pemberontakan Meniti Jalur Kanan, Jakarta: Grassindo. 1994.

Mcclellan, Erin D. 2011. Narrative as Vernacular Rhetoric: Understanding Community Among Transients, Tourists and Locals. Storytelling, Self, Society. Vol 7 (3): 188-210. DOI: 10.1080/15505340.2011.596089.

Millie, Julian. 2009. Splashed by the Saint: Ritual Reading and Islamic Sanctity in West Java. Leiden: KITLV Press.

Muzakkar, Kahar. 1955. Catatan Batin. Makassar: Terang Press.

Nicholas, Cheryl L. \& Kline, Kimberly N. 2010. Cerita Pontianak: Cultural Contradictions and Patriarchy in a Malay Ghost Story. Storytelling, Self, Society. Vol 6 (3): 194-211 DOI: 10.1080/15505340.2010.504408.

Powers, David S. 1986. Studies in Qur'an and Hadith: The Formation of the Islamic Law of Inheritance. Berkeley: University of California Press.

Powers, David S. 2010. Demonizing Zenobia: The Legend of al-Zabba' in Islamic Sources. In Histories of the Middle East: Studies in Middle Eastern Economy, Society, and Law in Honor of A.L. Udovitch. Leiden and Boston: Brill Press.

Saleh, Fauzan. 2001. Modern Trends in Islamic Theological Discourse in 2oth Century Indonesia: A Critical Study. Boston: Brill.

Salvatore, Armando, and Dale F. Eickelman. 2004. Muslim Publics. Public Islam and The Common Good. Ed. D. F. Eickelman and A. Salvatore. Pp. 3-28. Leiden and Boston: Brill.

Salvatore, Armando. 2004. Public Islam and the Common Good. In Public Islam and the Common Good. Ed. A. Salvatore and D. F. Eickelman. Pp. xi-xxv. Leiden and Boston: Brill.

Sahlins, Marshall. 1981. Historical Metaphors and Mythical Realities. Michigan: University of Michigan Press.

Skeiker, Fadi F. 2010. Once Upon a Time. Storytelling, Self, Society. Vol 6 (3):223-230. DOI:10.1080/15 505340.2010.504411. 
146 Moh Yasir Alimi, Muslims through Storytelling: Islamic Law, Culture and Reasoning ...

Soares, Benjamin F. 2004. Islam and Public Piety in Mali. In Public Islam and the Common Good. Ed. A. Salvatore and D. F. Eickelman. Pp. 205226. Leiden and Boston: Brill.

Tangke, Wanua. 2005. Misteri Kahar Muzakkar Masih Hidup. Makasar: Pustaka Refleksi.

Vandendorpe, Florence. 2011. When Myth Shows What the Mind Does Not Reach. Storytelling, Self, Society. Vol 7 (2): 91-109. DOI:10.1080/155 05340.2011.560800

Yuksel, Edip and Layth Saleh al-Shaiban. 2007. Quran: A Reformist Translation. USA: Brain- brow Press.

Zaman, Muhammad Q. 2007. The Ulama in Contemporary Islam: Custodians of Change. Princeton: Princeton University Press.

Zeghal, Malika. 2007. The "Recentering" of Religious Knowledge and Discourse: The Case of AlAzhar in Twentieth Century Egypt. In Schooling Islam: The Culture and Politics of Modern Muslim Education. Ed. R. W. Hefner and Q. M. Zaman. Pp. 107-130. Princeton: Princeton University Press. 